\title{
Az antiaritmiás szerek evolúciója, használata a kardiológiai intenzív terápiában
}

\author{
Zima Endre
}

\author{
Semmelweis Egyetem, Városmajori Szív- és Érgyógyászati Klinika, Budapest \\ Levelezési cím: Dr. Zima Endre, 1122 Budapest, Városmajor utca 68. E-mail: zima.endre@gmail.com
}

\begin{abstract}
A szívritmuszavarok incidenciája az életkor elörehaladtával, társbetegségek számával arányosan növekszik, az aritmiák az intenzív kezelés során a morbiditást és a mortalitást növelhetik. A ritmuszavarok gyakorisága és a potenciálisan súlyos kimenetel is indokolja az antiaritmiás gyógyszerpaletta fejlesztését. Az intenziv osztályokon, magas szintű őrzőkben kezelt betegek kis része alapvetően maga a ritmuszavar miatt kerül akut kezelésre, jelentősebb részük azonban az intenzív kezelést indokoló alapbetegség mellett szenved el szekunder ritmuszavart. Az antiaritmiás kezelés alapja az alapbetegség ismerete, az aritmia-mechanizmus feltérképezése. A nem ismert szívbetegséggel bíró betegek de novo aritmiája esetében alapvető a strukturális ok és az összes precipitáló faktor felmérése és korrigálása. Az aritmiák gyógyszeres kezeléséhez ismerni kell a szívizomsejtek elektrofiziológiai tulajdonságait, az aritmiák patomechanizmusait és a gyógyszer-hatástant. A számos, hosszú idő alatt kifejlesztett antiaritmiás szer történeti sarokpontjait foglalja össze e közlemény. A legtöbb szer ma már nem használható: az idő folyamán, elsősorban nagy randomizált vizsgálatokra alapozva, illetve kardiovaszkuláris, proaritmogén és nem szív-ér rendszeri mellékhatások miatt kiszelektálódtak. A gyógyszeres kezelésben elsősorban a bétareceptor-blokkolók, az amiodaron használható széleskörüen, mind szupraventrikuláris, mind kamrai tachyaritmiák akut kezelésében az intenzív osztályon.
\end{abstract}

Kulcsszavak: aritmiák, intenzív kezelés, antiaritmiás szerek fejlődése, proaritmia

\section{Antiarrhythmic agents: evolution and usability in the cardiac intensive care}

The incidence of arrhythmias is increasing in paralel with age and the number of underlying diseases of the patients. Arrhythmias may aggarvate the risk of further morbidity and mortality. The occurence and potentially fatal outcome urges the development of antiarrhythmic agents. Intensive or high dependency care is indicated by primary arrhythmia in a lower ratio of the cases, though a relatively high percentage of the patients treated in the intensive care unit due to their undelying diseases develop secondary arrhythmias. The fundamentals of antiarrhythmic drug treatment is to reveal the etiology and arrhythmia mechanisms. Patients with de novo arrhythmia should be investigated to find structural etiology and precipitating factors. Before drug treatment one should know the basic electrophysiological properties of cardiac cells, patomechanism of arrhythmias and pharmacology. This manuscript gives an overview on the historical milestones of the development of antiarrhythmic agents. Most of these drugs are not in use any more or contradicted due to the cardiovascular, proarrhythmic and non-cardiac side effects. In the present the most effective antiarrhythmics to treat both supravetricular and ventricular arrhythmias in the intensive care are beta-receptor blockers and amiodarone. Keywords: arrhythmias, intensive care, evolution of antiarrhythmiac agents, proarrhythmia

\section{Bevezetés}

A szívritmuszavarok megfelelő kezelése nagy jelentőséggel bír mind a populációs gyakorisága, mind a morbiditás és mortalitás-növelő hatása miatt. Az aritmiák kezelési lehetőségei egyrészt invazív, nonfarmakológiai eljárások (katéteres abláció, pacemaker, implantálható kardioverter defibrillátor beültetés), másrészt nem invazív, gyógyszeres kezelési stratégiák. A ritmuszavarok gyakorisága és a potenciálisan súlyos kimenetel is indokolja az alapvetően (újra) szerény lehetőségekkel rendelkező gyógyszeres terápia fejlesztését. Az eddigi kevés, igazán pozitív eredmény hátterében az aritmiák kezelésére használt gyógyszerek alkalmazhatósága áll. 


\section{Szívritmuszavarok az intenzív osztályon}

Az intenzív osztályokon, magas szintủ őrzőkben kezelt betegek kis része alapvetően maga a ritmuszavar miatt kerül akut kezelésre, jelentősebb részük azonban az intenzív kezelést indokoló alapbetegség miatt áll kezelés alatt, és a potenciális aritmia már szekunder módon alakulhat ki. Az intenzív terápiát igénylő betegek aritmiájának kezelése általánosságban nehezebb, noha az aritmia megjelenése nem különbözik egy „csak” aritmia miatt felvett betegétöl. Az aritmiák gyakoriak az átlagpopulációban és a kritikus állapotú betegeknél. A leggyakoribb forma a szupraventrikuláris tachycardia (SVT), mely gyakorisága kongesztív szívelégtelenségben $40 \%$, kritikus állapotú betegeknél 15\% körüli (3). Intenzív osztályos ellátás és anesztézia alatt mintegy $12 \%$ az aritmia előfordulási esélye, kardiovaszkuláris betegek esetén akár 30\%-ra is emelkedik. Az SVT legnagyobb arányban pitvarfibrilláció (AFib), kisebb arányban pitvari flattern (AFlu) és unifokális pitvari tachycardia. Az SVT ritkán oka az intenzív osztályos felvételnek, de gyakran már a felvétel első 2 napján kialakul. A kritikus állapotú - elsősorban szeptikus és légzési elégtelen - betegek esetén kialakuló SVT igazoltan magasabb mortalitással hozható összefüggésbe. $E$ betegeknél az SVT kialakulását potencírozó faktor az éltes kor, ismert, igazolt szívbetegség, diasztolés szívelégtelenség emelkedett pulmonalis artériás éknyomással. Az aritmiák kiváltó oka a nem megfelelő miokardiális oxigénigény-ellátás egyensúly, alacsony vérnyomás, perctérfogat és következményes perifériás oxigénellátás, valamint a célszervek károsodásából adódó gázcsere-defektus, illetve oliguria és elektrolitzavar, veseelégtelenség, májbetegség, már ismert korábbi ritmuszavar vagy aritmia szubsztrát (1). A légzési elégtelenség mellett emelkedő széndioxid kamrai extraszisztolékat generálhat. Hypoxaemia elöbb adrenerg hatáson keresztül tachycardizál, majd a progressziv hipoxia bradycardizál, akár aszisztóliát is okozhat.

Keringéstámogató gyógyszerek közül a pozitív inotróp ágensek tachycardizálnak, illetve proaritmiás hatásuk is lehet, elsősorban AFib-t okozhatnak. Ugyancsak nehézséget jelent, hogy számos, az alapbetegségböl adódó faktor emeli a szimpatikotóniát, reflex-tachycardiát okozva, például infekcióhoz társuló láz, vazodilatáció, vérzéshez társuló hypovolaemia, fájdalom, vagy éppen az intenzív osztályos környezet és beavatkozások (pl. intubáció, invazív eljárások).

Általános megállapítás, hogy a hypokalaemia mind pitvari, mind kamrai aritmiát okozhat, digitálisszal együtt elsősorban kamrai ritmuszavart generálhat (1).
$\mathrm{Az}$ irodalomban megoszlanak a vélemények a kritikus állapotú betegek szinte kötelezően megjelenő elektrolit-zavaraival kapcsolatban: noha sok közlés szerint az alacsonyabb szérum magnézium- és káliumszintek nem prediktorai az SVT kialakulásának, mégis a gyakorlatban mindig az élettani normálszint elérése a cél. Különösen érdemes erre törekedni azon idős szívbetegeknél, akiknél az esetlegesen szükséges katekolamin-támogatás miatt igen magas az AFib incidenciája. Azon betegek, akik súlyos szívbetegségben szenvednek és laktát-acidózisuk is kialakul, magasabb kockázatúak aritmia kialakulása szempontjából, mert a súlyos acidózis csökkenti a myocardium aritmia-küszöbét (2).

Bradycardiát okozhat a paraszimpatikus tónus fokozódása szemészeti, hasúri beavatkozások kapcsán, hasűri nyomás fokozódásával, fájdalommal. A bradycardia emelheti a bradydependens kamrai ritmuszavarok előfordulását, ám előbbi paraszimpatikolitikus és pozitív kronotróp gyógyszerekkel megfelelően kezelhető (2).

\section{Sebészeti beavatkozásokat kővető aritmiák az intenzív osztályon}

A posztoperatív SVT elsősorban AFib, kisebb arányban AFlu, illetve pitvari tachycardia formájában jelenik meg, 11-40\%-ban CABG-t, és akár 50\%-ban billentyűműtétet követően. A leggyakoribb aritmia-típus, amely ellátást és akár kórházi felvételt is igényel. Incidenciája az életkorral nő, $+5 \% 70$ éves kor felett, de életkortól függetlenül magasabb elhízottakban és obstruktív alvási apnoés betegeknél. Balkamra-diszfunkció esetén férfiaknál akár 4,5-szeresre, nőknél 5,9-szeresre emelkedik a kockázat, a szívelégtelenségben jellemző pitvari falfeszülés és fibrosis okozta elektromos és ioncsatorna-remodelling miatt.

Nem szívsebészeti mütéteknél a perioperatív perfúziózavar, a sebészi és aneszteziológiai beavatkozások miatti endogén és exogén keringő katekolaminok és következményes hypokalaemia, peritonitis, anémia, húgyúti fertőzés, cerebrovaszkuláris történés, tüdőembólia, gasztrointesztinális vérzés is lehet kiváltó tényező (4-6).

A szívsebészeti betegek aritmia mechanizmusához ebben a betegpopulációban a nem szívsebészeti betegek kockázati tényezőihez hozzáadódnak a perikardiális inflammáció vagy effúzió, a pericardium, illetve a myocardium direkt mechanikus inzultusa, a megemelkedett szérum katekolaminszintek, volumen-shift és a

Rövidítések:

AAD: antiaritmiás szerek; AFib pitvarfibrilláció; AFlu: pitvari flutter; APD: akciós potenciál időtartam; AVNRT: AV-nodális reentrty tachycardia; AVRT: AV reentry tachycardia; CABG: coronaria aoric bypass grafting; DAD: késői utódepolarizáció; DC sokk: direct current shock; EAD: korai utódepolarizáció; ICD: implantálható kardioverter defibrillátor; LVEF: bal kamrai ejekciós frakció; SNRT: sinus nodális reentry tachycardia; STEMI: ST-elevációs miokardiális infarktus; SVT: szupraventrikulári tachycardiák; VT: kamrai tachycardia; VF: kamrafibrilláció 
posztoperatív vegetatív változások. További kockázat: korábbi AFib-epizód, magas életkor, posztoperatív bétablokkoló-elvonás. Az aritmogenezisben ugyancsak szerepet kap az aorta zsírképleteinek eltávolítása, amely a vagális innervációt csökkenti $(7,8)$.

CABG-mútétet mintegy 1-6\%-ban követhet stroke, a posztoperatív pitvari tachyaritmiák háromszorosra emelik az esélyt. Nem növeli azonban a kockázatot a koszorúér-betegség súlyossága, a posztoperatív iszkémia, az aortás cross-clamp vagy az extrakorporális keringés időtartama, illetve a myocardium-védelem módszere. A fennálló tachyaritmia következménye lehet a hemodinamikai instabilitás, hosszas inotróp kezelés, intraaortikus ballonpumpa-kezelés igénye, antikoagulációs igény és fokozott vérzéskockázat miatti reoperáció igénye.

Szívsebészeti mütét után jelentkező, DC-sokkot vagy gyógyszeres kezelést igénylő kamrai aritmia akár a betegek 23\%-ában előfordulhat, ám malignus, nehezen uralható kamrai tachycardia (VT) vagy kamrafibrilláció (VF) elsősorban a csökkent bal kamra ejekciós frakciójú (LVEF) és a katekolamin infúziót igénylő posztoperatív alacsony perctérfogat szindrómás betegek esetében jön létre (9).

\section{Akut koronária szindrómához társuló arítmiák}

Akut ST-elevációs miokardiális infarktus (STEMI) esetén AFib akár 21\%-ban is előfordulhat, amely lehet már meglévő, vagy új keletü. STEMI és AFib együttes megjelenése rosszabb prognózisú a sinusritmusban levő STEMI-betegekével szemben (10).

Akut koronária szindrómában a vezető halálok a VT, illetve VF. A tünetek kezdetétől számított első 4 órában mintegy 4-18\%-ban alakulhat ki, kórházi felvételt követően mintegy $5 \%$-os az előfordulási gyakoriság (primer VF) az első 4 órában. A később megjelenő VT/VF elsősorban balkamra-elégtelenség, illetve kardiogén sokk mellett jön létre (szekunder VT/VF). A béta-bokkolók bevezetése, a trombolitikus éra, majd a katéteres revaszkularizáció az incidenciát jelentősen redukálta, de önmagában az akut STEMI-betegek 6-8\%-ában jelenhet meg hemodinamikailag releváns VT vagy VF (10-14). Az akut infarktusnál 3,6-9,8 \%-ban AV-blokk léphet fel, kezelésében elsőként választandó antibradykardia szer az atropin.

\section{A gyógyszeres kezelést meghatározó aritmia-mechanizmusok}

Az antiaritmiás kezelés alapja az alapbetegség ismerete, az aritmia pontos diagnózisát alátámasztó mechanizmus feltérképezése. A nem ismert szívbetegséggel bíró betegek de novo aritmiája esetében mindig alapvető a strukturális ok felmérése. Intenzív osztályon a ritmuszavarok kezelésében az általános antiaritmiás elvek követendőek, de előbb vagy párhuzamosan az összes precipitáló faktor korrigálandó, mert ezek fennmaradásával az aritmia-rekurrencia igen magas.

Az aritmiák gyógyszeres kezelésében alapvetően ismerni kell az szívizomsejtek elektrofiziológiai tulajdonságait, amelyek meghatározzák a ciklikus depolarzációt-repolarizációt, azaz az akciós potenciált. A sejtek felszínén található ioncsatorna-fehérje-komplexek határozzák meg az egyes sejtek akciós potenciáljának formáját és időtartamát, amelyek az antiaritmiás gyógyszeres kezelés molekuláris célpontjai. Az ioncsatornák funkcióját számos faktor képes modulálni: csatornafehérjék genetikai mutációja és expressziója, vegetatív tónus, elektrolit-eltérések és acidózis, akut hipoxia, iszkémia és reperfúzió, miokardiális hegképződés, exogén proaritmiás hatású gyógyszerek és katekolaminok (14). Abnormális automácia az a mechanizmus, amellyel valamilyen patológiás folyamat által részben depolarizált sejtekben impulzus alakul ki. A kevésbé negatív nyugalmi potenciál a fázis4 depolarizáció normál ionáramait és a pacemaker-potenciált inaktiválja.

Triggerelt akivitáson alapuló abnormális ingerképzés a membránpotenciál oszcillációján alapul, amelyet egy megelőző akciós potenciál vált ki. 2 típusa ismert: korai és késői utódepolarizáció (EAD ill. DAD). Előbbi az akciós potenciál 2-3. fázisában, utóbbi a depolarizáció végeztével jöhet létre.

Reentry talaján is alakulhat ki ritmuszavar, amelynek alapja 2 eltérő ingerületvezetési sebességű anatómiai szubsztrát, amely egyikén egy extraszisztólia unidirekcionális blokkot, azaz refrakteritást vált ki. Amíg a másik vezetőkötegen az ingerület eléri a már refrakter-időszakából „visszatérő”, depolarizálható fázisba kerülő köteget, az retrográd vezetést biztosít, amely az ingerületet az előbbi területre vezeti vissza, önmagába visszatérő elektromos kört alkotva.

A Sicilian Gambit besorolásának megfelelő táblázat az alábbiakban részletezi a mechanizmus szerint javasolt terápiás gyógyszercsoportot (1. és 2. táblázat) (15-18).

\section{Antiaritmiás gyógyszerek (AAD) to̊rténeti áttekintése}

Az első antiaritmiás szerként az Andokban őshonos kínafa (Cinchona officinalis) alkaloidákat tartalmazó kérgét, az ún. „Jezsuita kérget” írták le. Előbb használták általános lázcsillapítóként, majd 1630 körül felismerték, hogy a gyógynövény malária kezelésében hatékony. 1749-ben Jean-Baptiste de Sénac végzett kutatásokat a Cinchona kivonattal és megfigyelte annak antiaritmiás hatását. Az antiaritmiás hatású alkaloidákat 1860-ra izolálták, de az antiaritmiás hatást csak 1912-ben tudta egyértelműen igazolni Karel Frederik Wenckebach, miután egy világutazó kereskedő betege azt állította, 
1. TÁBLÁZAT. Ritmuszavarok mechanizmusai és a kívánt antiaritmiás gyógyszerhatás - automácia és triggerelt aktivitás (18)

\begin{tabular}{|c|c|c|c|c|}
\hline \multicolumn{2}{|c|}{ Mechanizmus } & \multicolumn{3}{|c|}{ Ritmuszavar } \\
\hline \multicolumn{2}{|c|}{$\begin{array}{l}\text { Fokozott automácia } \\
\text { Normális }\end{array}$} & \multicolumn{3}{|c|}{$\begin{array}{l}\text { Inappropriate sinus tachycardia } \\
\text { Unifokális pitvari tachycardia }\end{array}$} \\
\hline \multicolumn{2}{|c|}{$\begin{array}{l}\text { Fokozott automácia } \\
\text { Abnormális }\end{array}$} & \multicolumn{3}{|c|}{$\begin{array}{l}\text { Unifokális pitvari tachycardia } \\
\text { Akkcelerált idioventrikuláris ritmusok } \\
\text { Posztinfarktusos kamrai tachycardia }\end{array}$} \\
\hline \multicolumn{5}{|c|}{ Triggerelt aktivitás } \\
\hline \multicolumn{2}{|c|}{$\begin{array}{l}\text { Korai utódepolarizáció } \\
\text { (EAD) }\end{array}$} & \multicolumn{3}{|c|}{$\begin{array}{l}\text { Torsades de pointes KT } \\
\text { Digitálisz okozta aritmiák }\end{array}$} \\
\hline \multicolumn{2}{|c|}{$\begin{array}{l}\text { Késői utódepolarizáció } \\
\text { (DAD) }\end{array}$} & \multicolumn{3}{|c|}{ Egyes kamrai tachycardia típusok } \\
\hline \multicolumn{5}{|c|}{$\begin{array}{l}\text { 2. TÁBLÁZAT. Ritmuszavarok mechanizmusai és a kívánt } \\
\text { antiaritmiás gyógyszerhatás - Re-entry (18) }\end{array}$} \\
\hline \multicolumn{5}{|c|}{ Re-entry: Na-csatorna dependens } \\
\hline $\begin{array}{l}\text { Hosszú } \\
\text { excitábi- } \\
\text { lis rés }\end{array}$ & \multirow{2}{*}{\multicolumn{2}{|c|}{$\begin{array}{l}\text { Típusos pitvari flutter } \\
\text { AVRT } \\
\text { Monomorf VT } \\
\text { Atípusos pitvari } \\
\text { flutter } \\
\text { Pitvarfibrilláció } \\
\text { AVRT } \\
\text { Polimorf és mono- } \\
\text { morf VT } \\
\text { Tawara-szár re-entry } \\
\text { Kamrafibrilláció }\end{array}$}} & $\begin{array}{l}\text { Vezetés és } \\
\text { excitabilitás } \\
\text { csökkentése }\end{array}$ & $\begin{array}{l}\text { Na-csator- } \\
\text { na-blokkolók }\end{array}$ \\
\hline $\begin{array}{l}\text { Rövid } \\
\text { excitábi- } \\
\text { lis rés }\end{array}$ & & & $\begin{array}{l}\text { Refrakteritás } \\
\text { nyújtása }\end{array}$ & $\begin{array}{l}\text { K-csator- } \\
\text { na-blokkolók }\end{array}$ \\
\hline \multicolumn{5}{|c|}{ Re-entry: Ca-csatorna dependens } \\
\hline & \multicolumn{2}{|l|}{$\begin{array}{l}\text { AVNRT } \\
\text { AVRT } \\
\text { VT }\end{array}$} & $\begin{array}{l}\text { Vezetés és } \\
\text { ingerelhető- } \\
\text { ség } \\
\text { csökkentése }\end{array}$ & $\begin{array}{l}\text { Ca-csator- } \\
\text { na-blokkolók }\end{array}$ \\
\hline
\end{tabular}

hogy irreguláris szívverése ritmusos lett a Java-szigeteki őslakos „doktor” tanácsára Cinchona-ból

származó kinin bevétele után. Wenckebach Einthoven elektrofiziológiai laborjában EKG-regisztrátummal tudta bizonyítani a kinin hatására helyreálló sinusritmust egy betegen, bár többszöri próbálkozás után. 1918-ban Frey tanulmányozta a négy legfontosabb cinchona (kinidin, kinin, cinchonin, cinchoidin) hatását AFib-ban és végeredményben a kinidint találta közülük a legeffektívebb hatóanyagnak (19-21).

Az 1930-as években a szívsebészet úttörője, Claude Beck írta le a peri- és posztoperatív aritmiák gyakori megjelenését. Ezt a problémát Frederick $R$. Mautz vizsgálta kísérleteiben, majd 1936-ban publikálta eredményeit. Tanulmányaiban a nyálkahártyákról gyorsan felszívódó, és ismerten a szívre ható kokain-gyógyszercsaládot választotta. A procain, amely növeli a kamrai szívizomzat excitatorikus ingerküszöbét, megelőzi az esetlegesen kialakuló extraszisztolékat, és Mautz állatkísérleteiben hatékonyabbnak bizonyult, mint a kokain, továbbá kinidinhez hasonló hatását is sikerült igazolni. Mautz javallotta, hogy ha a szív egy bonyolult mútét során túlzottan aritmiássá

\section{Kívánt antiaritmiás hatás}

Depolarizáció csökkentése a IV. fázisban

Béta-blokkolók

Na-csatorna-blokkolók

Hiperpolarizáció elősegítése

Ca/Na-csatorna-blokkolók

vagy a depolarizáció csökken- Muszkarin-agonisták

tése a IV. fázisban

Akciós potenciál rövidítése vagy EAD elnyomása

Ca-többlet csökkentése vagy

DAD elnyomása

Szívfrekvencianövelő béta-agonisták, vagy vagolitikus ágensek, Ca-csatorna-blokkolók, béta-blokkolók,

Mg Ca/Na-csatorna-blokkolók, béta-blokkolók, adenozin

válik, intraperikardiális procain injekcióval szüntessék a ritmuszavart. A második világháború után kezdték általánosan alkalmazni a klinikumban a procaint, de a szervezet észteráz enzimei miatti rövid életideje és a központi idegrendszeri mellékhatásai behatárolták a klinikai használhatóságot. 1951-ben mutatták be az észterázrezisztens procain-analógot, a procainamidot, amely mai napig aktív klinikai használatban van. Krónikus aritmiakezelésre nem használható, mivel növeli az SLE-like szindróma kialakulásának kockázatát és idegrendszeri mellékhatása ugyancsak gyakori (22-23).

Löfgren, a Stockholmi Egyetemen tanító fiatal svéd kémikus 1943-ban fedezte fel az általa xylocainnak nevezett új lokális anesztetikumot, amely 1948-től lidocain néven került gyártásba és azóta tartó mindennapos orvosi felhasználásba. Később kiderült a hatóanyagról, hogy intravénásan beadva antiaritmiás hatással bír. 1950-ben írtak le egy esetet, miszerint szívkatéterezés közben sikeresen alkalmazták a szert DC-sokk mellett VF megszüntetésére (24).

Később számos, különösen szívsebészeti esetekben demonstrálták a lidocain hatékonyságát kamrai tachyaritmiákban. Flensted-Jensen és Sandøe vizsgálata szerint a lidocain nagy hatékonysággal használható kamrai extraszisztolék és DC-sokkal kombinálva VT-k esetében is (25).

Később azonban kiderült, hogy hiába szüntetheti a VT-s epizódokat a lidocain, növelheti az összmortalitást infarktus következtében kialakuló VT esetén. Mindennapos használata visszaszorult az amiodaron intravénás hatását mutató kísérletek megjelenését követően. A lidocain májban történő metabolizmusa korlátozza annak orális alkalmazását.

Az addig ismert antiaritmiás szerek mellékhatásai miatt a kutatók újabb, az 5-ös típusú nátriumcsatornán ható antiaritmiás szereket kísérleteztek ki, amelyek sorra jelentek meg a hidegháború alatt.

Az egyre növekvő számú antiaritmikum első rendszerezését Singh és Vaughan Williams dolgozták ki elektrofiziológiai tulajdonságaik alapján, négy különböző ezen belül I.A, I.B , II., III., IV. csoportot hoztak létre (26) (3. táblázat). 
3. TÁBLÁZAT: Az antiaritmiás szerek Vaughan-Williams szerinti besorolása $(26,27,28)$

\begin{tabular}{|c|c|c|c|c|}
\hline $\begin{array}{l}\text { Antiarit- } \\
\text { miás szer }\end{array}$ & $\begin{array}{l}\text { Osztályo- } \\
\text { zás }\end{array}$ & Indikáció & Hatásmechanizmus & IV/PO \\
\hline Ajmalin & \multirow{4}{*}{ I.A } & WPW, VT, Brugada teszt & \multirow{4}{*}{$\begin{array}{l}\text { 5-ös típ } \mathrm{Na}^{+} \text {-csatorna alfaalegység-gátló } \\
\text { (slows cond. velocity, prolongs ADP) }\end{array}$} & IV \\
\hline Disopyramid & & VT, AFib, HCM & & $\mathrm{PO}$ \\
\hline Procainamid & & $\begin{array}{l}\text { életet veszélyeztető aritmiák esetén: SVT, VT, } \\
\text { preexcitációs Afib }\end{array}$ & & IV/PO \\
\hline Quinidin & & AFib, AFlu, VT/VF & & IV/PO \\
\hline Lidocain & \multirow{4}{*}{ I.B } & VT/VF & \multirow{4}{*}{$\begin{array}{l}\text { 5-ös típ } \mathrm{Na}^{+} \text {-csatorna alfa-alegység } \\
\text { gátló (no efffect on cond. velocity, may } \\
\text { shorten } \mathrm{ADP} \text { ) }\end{array}$} & IV \\
\hline Mexiletin & & súlyos VT/VF & & $\mathrm{PO}$ \\
\hline Phenytoin & & SVT, VT/VF & & IV/PO \\
\hline Tocainid & & VT/VF & & $\mathrm{PO}$ \\
\hline Encainid & \multirow{4}{*}{ I.C } & AFib, AFlu, VT/VF & \multirow{4}{*}{$\begin{array}{l}\text { 5-ös típ } \mathrm{Na}^{+} \text {-csatorna alfaalegység-gátló } \\
\text { (slows conduction, may prolongs ADP } \\
\text { [mild]) }\end{array}$} & \\
\hline Flecainid & & VT/VF, atr. aritmia, SVT, AVNRT & & PO \\
\hline Moricizin & & VES, nonsustained VT & & $\mathrm{PO}$ \\
\hline Propafenon & & nonvalvularis AFib, PAF, parox. SVT, VT/VF & & $\mathrm{PO}$ \\
\hline Nadolol & \multirow{4}{*}{$\begin{array}{l}\text { II. (non- } \\
\text { szelektív } \\
\text { } \beta \text {-blokkoló) }\end{array}$} & nonvalvularis AFib & \multirow{4}{*}{$\beta_{1}$ és $\beta_{2}$ nem szelektív gátlása } & $\mathrm{PO}$ \\
\hline Propanolol & & $\begin{array}{l}\text { nonvalvularis AFib, SVT, VT, digitalis intox. vagy } \\
\text { katecholamin többlet miatti tachyarrhytmia }\end{array}$ & & PO \\
\hline Sotalol & & nonvalvularis AFib, AFib, súlyos VT/VF & & IV/PO \\
\hline Timolol & & ma már csak glaukóma esetén* & & ophtalmic \\
\hline Acebutolol & \multirow{6}{*}{$\begin{array}{l}\text { II. (szelektív } \\
\text { ß-blokkoló) }\end{array}$} & VES, VT/VF & \multirow{6}{*}{$\beta_{1}$ szelektív gátlása } & $\mathrm{PO}$ \\
\hline Atenolol & & VT/VF, SVT & & $\mathrm{PO}$ \\
\hline Betaxolol & & glaukóma és hipertenzió & & $\begin{array}{c}\mathrm{PO} / \\
\text { ophtalmic }\end{array}$ \\
\hline Bisoprolol & & $\begin{array}{l}\text { VES., nonvalvularis AFib, SVT, perioperatív } \\
\text { aritmiák }\end{array}$ & & $\mathrm{PO}$ \\
\hline Esmolol & & $\begin{array}{l}\text { SVT, intra- v. posztoperatív tachycardia, nonvalvu- } \\
\text { laris AFib, nem kompenzatív sinus tachycardia }\end{array}$ & & IV \\
\hline Metoprolol & & SVT, tachyarrhyhtmiák & & IV/PO \\
\hline Amidaron & \multirow{6}{*}{ III. } & $\begin{array}{l}\text { nonvalvularis AFib, SVT, VF, recurrens } \\
\text { hameodinamikailag nem stabil VT }\end{array}$ & \multirow{6}{*}{$\mathrm{K}^{+}$-csatorna blokkolók } & IV/PO \\
\hline Dofetilid & & rekurrens tünetes $\mathrm{AFib}$, tünetes $\mathrm{AFlu}$ & & $\mathrm{PO}$ \\
\hline Dronedaron & & nonvalvularis AFib & & $\mathrm{PO}$ \\
\hline Ibutilid & & gyakorian beálló nonvalvularis AFib, AFlu & & IV \\
\hline Sotalol & & $\begin{array}{l}\text { nonvalvularis AFib, AFlu, súlyos ventricularis } \\
\text { aritmiák }\end{array}$ & & $\mathrm{PO}$ \\
\hline Vernakalant & & nonvalvularis AFib & & IV \\
\hline Diltiazem & \multirow{2}{*}{ IV. } & nonvalvularis AFib, AFlu, PSVT & \multirow{2}{*}{$\mathrm{Ca}^{2+}$-csatorna blokkolók } & $\mathrm{PO}$ \\
\hline Verapamil & & nonvalvularis AFib, AFlu, PSVT & & $\mathrm{PO}$ \\
\hline Adenozin & \multirow{3}{*}{$\begin{array}{c}\text { nem } \\
\text { besorolható }\end{array}$} & PSVT, SVT & $A_{1}$-és $A_{2}$-purin receptor akt. & IV \\
\hline $\begin{array}{l}\text { Digitoxin/ } \\
\text { Digoxin }\end{array}$ & & krónikus AFib & \multirow{2}{*}{ Na/K ATP-áz gátlása } & IV/PO \\
\hline $\begin{array}{l}\text { Magnézium- } \\
\text { szulfát }\end{array}$ & & SVT, VT/NF & & IV/PO \\
\hline
\end{tabular}


Néhány új és nagyon hatékony nátriumcsatorna-blokkoló gyógyszer, úgymint encainid és flecainid felfedezésével Harrison és munkatársai egy harmadik alcsoportot, az I.C osztályt adta hozzá a rendszerezéshez (27).

Az antiaritmiás szerek utolsó csoportja ezen klasszifikációs séma szerint a IV. osztályba tartozó kalciumcsatorna-blokkolók (28).

A fenitoin egy neurológiában használt görcsoldó, amely I. B osztályra jellemző antiaritmiás hatással is bír, emiatt potenciális lehetőségként jön szóba tartós kamrai aritmiák kezelésénél, amikor más szerek ellenjavallottak vagy nem elérhetőek $(29,30)$.

A vegyület első leírása 1908-ban történt, Biltz benzilt használva szintetizálta a fenitoint. Dox és Thomas, két kémikus hipnotikus szerek kikísérletezése közben létrehozta a fenitoint, mint a barbiturátsav egyik fenilezett derivátumát. Megállapították, hogy a fenitoinnak nincsen hipnotikus hatása, éppen ezért évekig nem foglalkoztak vele. Később a tudomány fejlődésével kiderült, hogy egy potens antiepileptikumnak nem kell hipnotikus hatással bírnia, így Putnam végigpróbálta az összes olyan ismert vegyületet, ami szerkezetében hasonlít a fenobarbitálhoz, ismét eljutva a fenitoinhoz. 1936-ban igazolta görcsoldó tulajdonságát állatokon, azonban csak a következő évben lett az eredmény publikálva. Klinikai hatékonysága 1937-ben bizonyossá vált, azonban 1938-ig nem jelent meg publikációban az eredmény. 1938-ban jelent meg a szer a gyógyszerpiacon is (31-33).

A fenitoin antiaritmiás hatását a szívizomsejtek és a Purkinje-rostok membránján a nátrium-csatornákon keresztül fejti ki. Csökkenti a depolarizáció maximális sebességét, növeli az effektív refrakter periódust. Elsősorban az iszkémiás kamrai myocardium ektópiás aktivitását tudja csökkenteni. 1950-1970 között gyakran használt antiaritmikum volt, de a kevésbé toxikus szerek megjelenésével háttérbe szorult.

A Vaughan-Williams szerint I. C osztályba sorolható moricizin-hidroklorid 1964-ben a Szovjetúnióban lett először szintetizálva és továbbiakban használva, majd 1990-ben, a hidegháború lezárulásával az Egyesült Államokban is klinikai kivizsgálás alá került, ami alapján jóváhagyták, mint életet veszélyeztető kamrai aritmiák kezelésére használható gyógyszert. A hatóanyag kémiailag nem függ össze semmilyen manapság használatban levő antiaritmiás szer szerkezetével, fenotiazin származék, azonban nem vált ki dopamin-antagonista aktivitást, viselkedési és autonóm idegrendszeri hatást. Az antiaritmiás hatás kiváltásához szükséges dózis számos és változatos mellékhatással jár. A CAST-study rámutatott arra, hogy hiába nyomja el a szer a tünetmentes kamrai befogott ütéseket, nem javítja szignifikánsan a vizsgált betegcsoport mortalitását, így a moricizinnel végzett vizsgálatot idejekorán megszakították. Ez a mérföldkő vizsgálat mutatott rá arra, hogy az antiaritmiás gyógyszerek esetében is mennyire fontos mérlegelni a kezelés előnyös hatásait, valamint an- nak kockázatait. A szert 2007-ben proaritmiás hatása és financiális okok miatt kivonták a forgalomból (34). A disopyramidot 1977-ben mutatták be az Egyesült Államokban. A disopyramid csökkenti a szív automáciáját, növeli a refrakter periódust és lassítja az ingervezetést. Mellékhatása a myokardium deprimáló, kontraktilitás-csökkentő és antikolinerg hatás, ezért szívelégtelenségben használata ellenjavallt. A szer kiválóan alkalmazható speciális esetekben hipertrófiás cardiomyopathiához kapcsolódó tachyaritmiákban, de paroxizmális AFib-ban is. A klinikai vizsgálatok során a disopyramid adása összefüggött az aminotranszferáz és alkalikus foszfatáz szérumszintjének növekedésével, azonban széles körü használata ellenére nagyon ritkán okoz tünetes, klinikai májkárosodást $(35,36)$.

Szükségessé vált a lidocainhoz hasonló szerkezeti és antiaritmiás tulajdonságokkal bíró vegyületek fejlesztése. Így vált elérhetővé az antiaritmiás gyógyszeres terápiában a tocainid 1984-ben és a mexiletin 1986-ban. A lidocain strukturális analógja, a tocainid kikerüli a májmetabolizmust és orálisan adva a biohasznosulása közel $100 \%$. A kamrai aritmiáknak a megelőzésében és a terápiájában hatékony szerként mutatták be miokardiális infarktus után, mind rövid- és hosszú távú beállítással. Hatása a krónikus komplex ektópiás kamrai ütések elnyomásában nyilvánul meg, így megelőzi a malignus VT-k kialakulását, AFib és AFlu esetén azonban nem használható antiaritmikumként (37).

A Vaughan Williams I.B osztályba sorolt szerek toxicitása dózisfüggő, mégis gyakori a potenciálisan életet veszélyeztető mellékhatások megjelenése. A gyógyszerelés felfüggesztésével ezek a mellékhatások gyorsan szűnnek. A lidocain, tocainid és mexiletin általános mellékhatásai szédülés, zavartság, görcsroham, légzésdepresszió, gasztrointesztinális tünetek. Kardiovaszkuláris mellékhatás a magasfokú AV-blokk, negatív inotróp hatás, hipotónia, aszisztólia. A tocainidnek és mexiletinnek proaritmiás hatása is ismert. A szerek eliminációja romlik szívelégtelenségben, tocainidé veseelégtelenségben, lidocainé és mexiletiné májelégtelenségben.

1963-ban Vaughan Williams kimutatta, hogy egy az eddigiektöl teljesen különböző gyógyszer, a béta-adrenerg-receptor-blokkoló pronethanol szintén antiaritmiás aktivitással rendelkezik, hasonlóan a disopyramidhoz és a kinidinhez. Későbbiekben ez a bétareceptor-blokkolók számos formájának fejlesztését indította el (38). A béta-blokkolók a mai napig ismert, az egyik leghatékonyabb mortalitást csökkentő "gyógyszercsalád".

Jelenleg a klinikai gyakorlatban igen kevés nátriumcsatorna-blokkolót alkalmazunk a ritmuszavarok gátlására, a számos antiaritmiás vizsgálat ellenére. Az alkalmazott gyógyszerek alacsony száma összefügg a Cardiac Arrhythmia Suppression Trial (CAST), a CAST-II tanulmány és sok kisebb vizsgálatok eredményeivel $(39,40)$. A nátriumcsatorna-blokkoló antiaritmiás szerek hatéko- 
nyan gátolhatják a ritmuszavarokat, ez azonban nem feltétlenül javítja a túlélési arányt miokardiális infarktust követően (41).

A Cardiac Aritmia Suppression Trial (CAST) tisztán igazolta a korábban hatékonynak és jótékonynak tartott antiaritmiás szerek potenciálisan végzetes mellékhatását. A vizsgálatot a tervezettnél korábban leállították, mivel a 3 vizsgált I.A szer közül az enkainid és a flekainid ágán 3,6-szoros aritmia halálozást, illetve nem végzetes keringésmegállást igazoltak $(39,40)$.

Az 1980-1990-es évek során az akciós potenciál időtartamát és a refrakteritást nyújtó gyógyszerek (pl. a III. osztályú káliumcsatorna-blokkoló szerek) fejlesztése került előtérbe. Ennek hátterében az I. típusú szereknek a CAST eredményét is negatívan befolyásoló proaritmiás hatása, másrészt a sotalol és amiodaron klinikai hatékonysága áll. Ezt erősítették a hosszú távú, amiodaronnal kapcsolatos tanulmányok, amelyek a szer posztinfarktusos aritmia eredetű halálozást csökkentő hatékonyságát bizonyították béta-blokkolóval való együtt adás esetén. (42-44).

A káliumcsatornák a nyugalmi membrán potenciált stabilizálják, szabályozzák a sejtek repolarizációs folyamatait. Feszültségfüggő káliumáramok, úgymint késői rektifikáló és befelé rektifikáló káliumcsatornák, az acetilkolin által szabályozott csatorna együtt határozzák meg a membrán elektromos állapotát.

A nátriumcsatorna-blokkolókkal kapcsolatos klinikai vizsgálatokhoz hasonlóan a sotalolt és amiodaront alkalmazó tanulmányok igazolták, hogy hatékonyan csökkentik a kamrai extraszisztolék számát és a mortalitást, azonban ritkán megnyúlhat a QT-intervallum, amely torsades de pointes (TdP) aritmia fellépéséhez vezethet (43-46).

Ugyanakkor más közlemények arra utalnak, hogy az antiaritmiás gyógyszerek, mint például az amiodaron „kevert” ioncsatorna-blokkoló tulajdonságának köszönhető az aritmia kiváltását mérséklő hatás $(47,48)$.

Az amiodaron és a sotalol klinikai vizsgálatok által igazolt egyértelmű hatékonysága ellenére számos egyéb, kizárólag III. osztályú szert is vizsgáltak a gyógyszerfejlesztések során: a dofetilid, az ibutilid, az azimilid rendkívül hatékony, ioncsatorna szelektív blokkolók, amely révén AFib és AFlu ellenes hatással is rendelkeznek, valamint kamrai tachyaritmiák esetén is hatékonyak $(49,50)$. A dofetilid szelektíven blokkolja a késői rektifikáló káliumáram gyors komponensű csatornáját $\left(I_{K r}\right)$ (51). Az ibutilid nem csupán az $I_{K r}$-t blokkolja, hanem egyidejüleg fokozza a nátrium-áramot, az azimilid pedig számos káliumcsatornát blokkol (52). Az azimilid az $I_{\mathrm{Kr}}$-t és a késői rektifikáló káliumáram lassú komponensű csatornáját $\left(I_{\mathrm{Ks}} \mathrm{t} t\right)$ is blokkolja (53). A III. osztályú szerek kifejlesztésén túlmenően olyan gyógyszerek létrehozása a cél, amelyek egyidejüleg több ioncsatornát blokkolnak a szívben. A káliumcsatorna-blokkoló önmagában történő alkalmazásának korlátja lehet az APD megnyúlása, amely bradycardiát eredményezhet, mindemellett hatékonyak a megnyúlt APD fenntartásában lassú szívfrekvencia esetén. Magas szívfrekvencia mellett ezeknek a szereknek a hatékonysága jelentősen csökken, ez a „reverse use-dependence” jelenség $(54,55)$.

Kizárólag az amiodaron nem rendelkezik ezzel a hatással, és máig ez a legpotensebb antiaritmiás gyógyszer a kezünkben, amelyet mind SVT, mind VT/VF esetén igen jó effektussal alkalmazni tudunk (56).

\section{Antiaritmiás szerek mellékhatásai és veszélyei}

Az antiaritmiás szerek széles körű használatával felismerésre került potenciális proaritmiás hatás, nem kardiovaszkuláris mellékhatások miatt közülük számos gyógyszer ma már nem, vagy csak korlátozott indikációval alkalmazható $(57,58)$.

A proaritmia definíciószerüen a Holterrel vagy terheléses vizsgálattal igazolt VES-szám emelkedést, a klinikai aritmia súlyosbodását, vagy kamrai ritmuszavarok, bradycardia megjelenését jelenti. A leggyakrabban közvetlenül a gyógyszer indítása után jelenik meg a nem kívánt hatás, de a késői aritmia-megjelenés sem elhanyagolható probléma, amely alapja a gyógyszer-indukálta QT-megnyúlás, illetve a nátriumcsatorna-blokkoló hatás. Utóbbiak közül a hosszan tartó blokkoló hatással bírók a legproaritmiásabbak, elsősorban a lassú szívfrekvencia és lassú vezetés mellett (I.C flekainid, propafenon). Azon nátriumcsatorna-blokkolóknál, amelyeknél gyors a blokk időállandója és a blokk elsősorban magas kamrafrekvencia mellett kifejezettebb, kisebb a proaritmiás hatás (I.B lidocain, mexiletin). III. osztályú AAD és a kinidin proaritmiás hatása elsősorban a QT-intervallum megnyúlásától függ.

Az egyik elsőként leírt proaritmiát, a „kinidin-szinkopét” nem tartós VF, illetve polimorf VT okozza. Gyógyszertípustól függően 5,9-15,8\%-ban fordulhat elő proaritmiás hatás az antiaritmiás szerek esetében.

A proaritmia mechanizmusa egyrészt az ingervezetés lassításán és az abnormális automácián alapul. A vezetés lassításával és lokális unidirekcionális blokk létrehozásával egy funkcionális reentry-szubsztrát jöhet létre, amely képes lesz „felvenni”(excitábilis rés) és vezetni az automáciából származó elektromos hullámfrontot, amit nem olt ki a reentry-kör refrakter része (azaz elég lassan vezetődik). Az AAD-k egyike sem gyorsítja a vezetést, sőt, az erőteljesebb lassító hatás magasabb proaritmiás kockázattal jár együtt.

Az effektív refrakter periódus nyújtása (I.A, III. osztályú $A A D)$ az antiaritmiás hatást az excitábilis rés elnyomásán keresztül fejti ki, azaz a hullámfront a refrakter periódust eléri, „kioltódik”, és a proaritmiás hatásuk is csökken ezáltal. Az I.B szerek a refrakter periódus rövidítésével magasabb proaritmiás hatással bírnak. Az abnormális automáciát az AAD-k jelentős része el tudja 
nyomni, kivéve, ha az korai utódepolarizáción (early after-depolarisation, EAD) alapuló triggerelt aktivitás. I.A és III. AAD-k és számos nem AAD tudja növelni az EAD megjelenési gyakoriságát, amely a frekvencialassítás és a QT-megnyúlás miatt növeli a proaritmiás hatást. $A z$ EKG-n ilyenkor bizarr T-U-hullámok, VES, illetve kamrai aritmiák, elsősorban TdP jelennek meg. Minden antiaritmiás szer a vezetés lassításával és az automácia elnyomásával bradyaritmiát is okozhat, ezek közül a digoxin különösen fontos, mivel a késői utódepolarizáción (delayed, DAD) alapuló triggerelt aktivitást váltja ki.

Ugyancsak nem elhanyagolható szempont, hogy a különböző ioncsatorna támadáspontú AAD-k kombinációja exponenciálisan növeli a proaritmiás hatást.

Szegedi munkacsoport igazolta, hogy az önmagában adagoltan nem vagy minimálisan proaritmiás $I_{\mathrm{Kr}}$ (gyors komponensű késői Kálium-egyenirányító) blokkoló dofetilid és az I Is (lassú komponensű késői Káliumegyenirányító) blokkoló HMR-1556 kombinációja $\mathrm{QT}_{\mathrm{c}}$-nyújtó hatású és ezzel együttesen jelentkező magas torsadogen hatást hoz létre (59).

Az ugyancsak I.A osztályú, korábban WPW és kamra tachycardia kezelésére használt alkaloida, az ajmalin ma már döntően a Brugada-szindróma diagnózisának felállításában jut szerephez. Intravenásan adva ST-elevációt vált ki $\mathrm{V}_{1-3}$ elvezetésekben az érintett betegeknél. Antiaritmiás gyógyszerek proaritmiás hatásait fokozó tényezők a toxikus gyógyszerszint kialakulását segítő tényezők: időskor, szív-, vese-, májelégtelenség, aritmia szubsztrát, digoxin kezelés, elektroliteltérések, bradycardia, hasonló hatású AAD-k együttes adása.

\section{Antiaritmiás kezelés az intenzív osztályon 2017-ben - Mi maradt a kezünkben?}

A kezelés módja intravénás, per os kezelés vagy ezek kombinációja. A kezelés módja lehet profilaktikus, telítő és fenntartó. Hemodinamikailag instabil vagy extrém tünetekkel rendelkező beteg azonnali kardioverziót igényel. Stabil betegeket lehet gyógyszeresen kezelni.

\section{Intenzív osztályon észlelt SVT ellátása, frekvenciakontrollja}

Antiaritmiás szerekkel csak akkor lehet ellátni a beteget akut aritmia esetén, ha stabil a keringése. Digoxin ritkán ad megfelelő frekvenciakontrollt, elsősorban a fokozott endogén szimpatikotónia és az esetleges exogén katekolaminok miatt, de kihasználható a lassan kialakuló pozitív inotrop hatása (60).

Szérumszinttől függetlenül az intravénásan (iv.) adagolt magnézium megfelelő frekvenciakontrollt biztosíthat, azonban vazodilatáció, hipotónia is együtt jár vele. Keringési elégtelenség miatt katekolamin-támogatásban részesített betegeknél az amiodaron megfelelő frekvenciakontrollt biztosított (61).
Hemodimaikailag stabil betegeknél a béta-blokkolók alkalmazása jelenleg az elsőként választandó frekvenciakontrollra (62).

\section{Supraventricularis tachyaritmiálk kezelése (62)}

Sinus tachycardia

A terápia az aritmia okának megszüntetését (pl. hipovolémia, láz, anémia, hyperthyreosis) célozza. Bétablokkolók, kalciumcsatorna-gátlók, ivabradin szükséges lehet a frekvenciakontrollhoz. Refrakter esetben sinuscsomó modifikálás megfontolandó katéteres ablációs módszerrel.

Sinus nodális re-entry tachycardia (SNRT) Vagus manőver vagy iv. adott adenozin sikeresen terminálhatja. „Rapid atrial pacing” szintén alkalmazható ilyen esetben. Béta-blokkolók, kalciumcsatorna-gátlók és digoxin a rekurrencia megelőzésében lehetnek hasznosak. Abláció csupán ritkán szükséges.

\section{Pitvari flattern (AFlu)}

Terápiája nagyban hasonlít a AFib esetéhez. Kamrai frekvenciakontroll érdekében béta-blokkolók, kalciumcsatorna-gátlók használata javasolt I.A és I.C terápia bevezetéseként. Utóbbiak javítják az AV-csomó ingervezetését vagolitikus hatásuk által, továbbá olyan szintre csökkentik a pitvari frekvenciát, hogy potenciálsan 1:1 AV-vezetést hoznak létre, amely eredménye magasabb kamrafrekvencia, ezért béta-blokkolókkal való kombinációjuk javasolt.

Antiaritmiás szerek alkalmazása elektromos kardioverzó előtt elősegítik a beavatkozás utáni sinusritmus fennmaradását és csökkentik a AFlu-ből AFib-ba történő konverziót. „Rapid atrial pacing” nyitott szívmütét után epikardiális pitvari elektródán keresztül, illetve pacemakeres betegnél pitvari elektródán keresztül lehetséges. A cavotricuspidalis isthmus radiofrekvenciás ablációja $90 \%$ feletti hatékonysággal hosszú távon megszünteti a AFlu-t.

\section{Multifokális pitvari tachycardia}

A terápia a ritmuszavar etiológiai betegségét célozza, itt az antiaritmiás szereknek kisebb szerep jut. Kalciumcsatorna-blokkolók magasabb dózisban, illetve amiodaron hasznosnak bizonyulhat. Elektrolit egyensúly fenntartása, különösképpen megfelelő kálium- és magnéziumszintek elősegítik a multifokális tachyaritmia megelőzését.

\section{AV-nodális re-enrty tachycardia (AVNRT)}

Igazolt AVNRT esetén a radiofrekvenciás abláció 95\%-os sikerrel alkalmazható, valamint elkerülhető a hosszú távú szuppresszív gyógyszeres terápia. Béta-blokkolók, kalciumcsatorna-gátlók, digoxin és adenozin lassítják vagy blokkolják az anterográd lassú pályákat, míg I.A és I.C osztályú antiaritmiás sze- 
rek lelassítják a vezetést a retrográd gyors pályán. Akut ellátásban az adenozin az elsővonalbeli antiaritmiás szer az AVNRT terminálásában, azonban csak intravénásan adható és nagyon rövid, 6-9 másodperces féléletidővel rendelkezik. Intravénás vagy orális béta-blokkolók, kalciumcsatorna-gátlók másodrangú szerként használatosak, ha adenozin nem bizonyul sikeresnek. Elektromos kardioverzió megfontolandó instabil hemodinamikai állapotú, tünetes betegek esetében. Alacsony energiájú 10-50 J kardioverzió alkalmas AVNRT terminálásához.

\section{AV re-entry tachycardia (AVRT)}

Mindkét típusú AVRT (orthodrom, antidrom), keskeny QRS-sel járó tachycardia AV-csomó dependens, ezért az AV-csomót blokkoló terápiára és vagus manőverekre jól reagál. Transzvénás vagy transoesophagealis pitvari ingerlés is képes az ilyen típusú tachycardiát terminálni. Az adenozin effektív orthodrom és antidrom AVRT esetén, de AFib esetén Wolff-Parkinson-White-szindrómában életet veszélyeztető lehet, mivel az akcesszorikus köteg lassítás nélkül vezeti a kamrákra a magas frekvenciájú AFib-t, VF-t eredményezve.

Széles QRS-sel jár a tachycardia, ha az orthodrom AVRT aberránsan vezetődik a kamrákra, illetve ha az AVRT antidrom formájú, vagy pitvari aritmia (AT/AFlu/ AFib) anterográd vezetődik egy akcesszorikus pályán. Ilyen esetben a széles QRS mechanizmusának meghatározása gyakran nehéz, ezért az accessoricus pálya vezetését lassító szerek alkalmazandóak: procainamid, flecainid, sotalol vagy amiodaron. Az anterográd accessoricus pályán levezetődő pitvari aritmiák nem AV-csomó dependensek, ezért AV-csomót blokkoló terápiák ineffektívek, mindemellett potenciálisan kamrai ritmuszavart generálhatnak. Perzisztáló tachycardia esetén, szinkronizált elektromos kardioverzió használata a választandó terápia. Radiofrekvenciás abláció 85-98\%-ban sikeres az accessoricus nyaláb lokalizációjától függően.

\section{Akut AFib frekvenciakontrollja}

Frekvenciakontroll céljából béta-blokkolók, digoxin, diltiazem vagy verapamil adása javasolt AFib-betegeknek, ha a LVEF $>40 \%$, azonban alacsonyabb EF esetén csak béta-blokkolók és/vagy digoxin. Ezen szerek kombinálására lehet szükség a megfelelő szívfrekvencia-célérték elérése érdekében. Hemodinamikailag instabil vagy súlyosan csökkent LVEF esetén amiodaron adható akutan a szívfrekvencia csökkentésére.

\section{AFib ritmuskontrollja, kardioverziója}

Hemodinamikailag instabil AFib esetén akut esetben elektromos kardioverzió javasolt. Perzisztens vagy tar- tósan perzisztens tünetes AFib-betegeknél javasolt elvégezni az elektromos vagy gyógyszeres kardioverziót. Az elektromos kardioverzió sikerének növelése és a rekurrencia megelőzése céljából amiodaron, flecainid, ibutilid vagy propafenon előkezelés javasolt.

Amennyiben strukturális és/vagy iszkémiás szívbetegség áll fenn, amiodaronnal javasolt végezni az AFib kardioverzióját. Iszkémiás vagy strukturális szívbetegség hiányában flecainiddel, propafenonnal vagy vernakalanttal, ibutiliddel végezhető gyógyszeres kardioverzió újonnan felismert Afib esetén.

Szívműtét utáni posztoperatív AFib megelőzése céljából a perioperatív időszakban béta-blokkolók adása javasolt szájon át, és indokolt lehet a perioperatív időszakban amiodaron-profilaxis folytatása (62).

\section{Ventricularis tachyaritmiák kezelése}

Általánosságban elmondható hogy a VT-k kezelését a hemodinamikai állapot határozza meg. Elektromos kardioverzió választandó elsőként az instabil állapotú betegeknél.

Stabil betegeknél specifikus antiaritmiás kezelés beállítása mellett az etiológia tisztázása és az alapbetegség kezelése (pl. iszkémia esetén revaszkularizáció, illetve a fennálló szívelégtelenség kezelése), az elektrolitegyensúly korrigálása javasolt.

Pulzus nélküli VT és VF esetében kardioverzió/defibrilláció javasolt 200-360 J energiával. Fontos a minőségi kardiopulmonalis reszuszcitáció, effektív mellkaskompresszióval, minimális megszakítással. Az ERC 2015 ajánlása szerint akut gyógyszeres terápia az intravénás amiodaron, másodvonalban lidocain. Elkeseredett esetekben jön csak szóba a procainamid, béta-blokkolók adása.

Amiodaron választandó ismételt VT/VF-epizódok esetében. Amiodaron mellett másodvonalbeli szerként lidocain ajánlott balkamra-diszfunkcióval rendelkező betegek esetében (bal kamrai ejekciós frakció $<40 \%$ ). Lidocain iszkémiás eredetű VT-ben is adható. Procainamid stabil monomorf VT esetében effektívebben biztosít korai frekvenciacsökkenést és konverziót mint az amiodaron, de hipotonizáló, negatív introp hatása miatt csak harmadvonalbeli szerként javasolt. Béta-blokkolók akut koronária szindróma esetében javallottak ritmuszavar megelőzésében. Bradycardia-dependens VT esetén ideiglenes pacemakerrel magasabb frekvencia beálítása is szükséges lehet. Gyógyszer-proaritmia okozta VT esetében az ágens elhagyása, esetleg antidotum adása szükséges. III. osztályú ágensek és béta-blokkolók hatásosak profilaktikus terápiaként. A hirtelen szívhalál megelőzésében átütő mortalitáscsökkentést az implantálható kardioverter defibrillatorok hoztak. Az antiaritmiás gyógyszeres terápia főként a ritmuszavarok rekurrenciájának csökkentésében, kiegészítésként hatásos az ICD mellett. Kalcium-blokkolók használata idiopátiás bal kamra 
VT-ben vezethet eredményre. Radiofrekvenciás abláció a VT típusától függően lehet hatásos (62).

\section{Akut koronária szindrómához társuló VT/ VF megelözése és ellátása}

Béta-blokkolók adása javasolt visszatérő, iszkémiás eredetú polimorf VT esetén, ugyancsak elsővonalbeli szerként ajánlott intravénás amiodaron adása. Per os béta-blokkoló kezelés megfontolandó a kórházi kezelés során, majd a későbbiekben is minden akut koronária szindrómán átesett betegen, amennyiben kontraindikáció nincs. Intravénás lidocain adása szóba jön visszatérő VT kezelésére, amennyiben a béta-blokkoló és az amiodaron hatástalan vagy kontraindikált (63).

\section{Következtetések}

A számos, nagy erőfeszítéssel, hosszú idő alatt kifejlesztett antiaritmiás szer közül a legtöbb szer ma már nem használható: az idő folyamán, elsősorban nagy randomizált vizsgálatokra alapozva, illetve kardiovaszkularis, proaritmogén és nem szív-ér rendszeri mellékhatások miatt kiszelektálódtak. Ugyancsak beszűkíti az indikációs kört amennyiben a beteg iszkémiás szívbetegségben, dilatatív cardiomyopathiában is szenved. A gyógyszeres kezelésben elsősorban a bétareceptor-blokkolók, az amiodaron használható széleskörűen, mind szupraventrikuláris, mind kamrai tachyaritmiák akut kezelésében az intenzív osztályon. A kezelés szofisztikált beállításában figyelembe kell venni a gyógyszer-interakciókat, potenciális proaritmás hatást és az aritmia kialakulásának körülményeit, mechanizmusát.

\section{Irodalom}

1. Artucio $H$, Pereira M. Cardiac arrhythmias in critically ill patients: epidemiologic study. Crit Care Med 1990; 18: 1383-8.

2. Nordrehaug JE, Johannessen KA, von der Lippe G. Serum potassium concentration as a risk factor of ventricular arrhythmias early in acute myocardial infarction. Circulation 1985; 71: 645-9. https://doi. org/10.1161/01.CIR.71.4.645

3. Ommen SR, Odell JA, Stanton MS. Atrial arrhythmias after cardiothoracic surgery. N Engl J Med 1997; 336: 1429-34. https://doi. org/10.1056/NEJM199705153362006

4. Walsh SR, Tang T, Wijewardena C, et al. Postoperative aritmias in general surgical patients. Ann R Coll Surg Engl 2007 Mar; 89(2): 91-5. https://doi.org/10.1308/003588407X168253

5. Atlee JL. Perioperative cardiac dysrhythmias: diagnosis and management. Anesthesiology 1997; 86: 1397-424. https://doi org/10.1097/00000542-199706000-00026

6. Ellenbogen KA, Chung MK, Asher CR, Wood MA. Postoperative atrial fibrillation. Adv Card Surg 1997; 9: 109-30.

7. Perzanowski C, Gandhi S, Pai RG. Incidence and predictors of atrial fibrillation after aortic repairs. Am J Cardiol 2004; 93: 928-30. https://doi.org/10.1016/j.amjcard.2003.12.039

8. Falk RH. Medical progress: atrial fibrillation. N Engl J Med 2001;
344: 1067-78

9. Ferraris VA, Ferraris SP, Gilliam HS, et al. Predictors of postoperative ventricular dysrrhythmias: a multivariate study. J Cardiovasc Surg (Torino) 1991; 32: 12-20.

10. Schmitt J, Duray G, Gersh BJ, Hohnloser SH. Atrial fibrillation in acute myocardial infarction: a systematic review of the incidence, clinical features and prognostic implications. Eur Heart J 2009; 30: 1038-1045. https://doi.org/10.1093/eurheartj/ehn579

11. Teo KK, Yusuf S, Furberg CD. Effects of prophylactic antiarrhythmic drug therapy in acute myocardial infarction: an overview of results from randomized controlled trials. JAMA 1993; 270: 1589-95. https://doi.org/10.1001/jama.1993.03510130095038

12. Maggioni AP, Zuanetti G, FranzosiMG, et al. Prevalence and prognostic significance of ventricular arrhythmias after acute myocardial infarction in the thrombolytic era: GISSI-2 results. Circulation 1993; 87: 312-22. https://doi.org/10.1161/01.CIR.87.2.312

13. Solomon SD, Ridker PM, Antman EM. Ventricular arrhythmias in trials of thrombolytic therapy for acute myocardial infarction: a meta-analysis. Circulation 1993; 88: 2575-81. https://doi. org/10.1161/01.CIR.88.6.2575

14. Shah M, Akar FG, Tomaselli GF. Molecular basis of arrhythmias. Circulation 2005; 112: 2517-29. https://doi.org/10.1161/CIRCULATIONAHA.104.494476

15. Hoffman BF, Rosen MR. Cellular mechanisms for cardiac arrhythmias. Circ Res 1981; 49: 1-15

16. Binah O, Rosen MR. Mechanisms of ventricular arrhythmias. Circulation 1992; 85 (suppl 1): 25-31.

17. Wit AL, Cranefield PF. Reentrant excitation as a cause of cardiac arrhythmias. Am J Physiol 1978; 235: H1-17.

18. The Sicilian gambit: a new approach to the classification of antiarrhythmic drugs based on their actions on arrhythmogenic mechanisms. Circulation 1991; 84: 1831-51.

19. Burch GE, DePasquale NP (1990). A history of electrocardiography. San Francisco: Norman

20. Katz LN. Quinidine. Journal of the American Medical Association 1948; 136: 1028.

21. Nattel S, Singh BN. Evolution, mechanisms, and classification of antiarrhythmic drugs: focus on Class III actions. Am J Cardiol 1999; 84:11R-19R. https://doi.org/10.1016/S0002-9149(99)00697-9

22. Mark LC, Kayden HJ, Steele JM, et al. The physiological disposition and cardiac effects of procainamide. J Pharmacol Exp Ther 1951; 102: 5-15.

23. Hollman A. Procain and procainamide. Heart 1992; 67: 143-143. https://doi.org/10.1136/hrt.67.2.143

24. Southworth JL, McKusick VA, Pierce EC, Rawson FL. Ventricular fibrillation precipitated by cardiac catheterization. Complete recovery of a patient after 45 minutes. J Amer Med Assoc 1950; 143: 717. https://doi.org/10.1001/jama.1950.02910430009003

25. Flensted-Jensen E, Sandøe E. Lidocaine as an antiaritmic agent. Acta Medica Scandinavica 1969; 185: 297-302. https://doi. org/10.1111/j.0954-6820.1969.tb07337.x

26. Vaughan Williams EM. Classification of anti-arrhythmic drugs. In: Sandoe E, Flensted-Jensen E, Oleson KH, editors. Cardiac arrhythmias. Sweden: Astra; 1970. P. 449-472. https://doi. org/10.1007/978-3-642-73666-7_2

27. Harrison DC, Winkle RA, Sami M, Mason JW. Encainide: a new and potent antiarrhythmic agent. In: Harrison DC, editor. Cardiac arrhythmias: a decade of progress. Boston: GK Hall Medical Publishers; 1981. P. 315-330. https://doi.org/10.1016/0002-8703(80)90212-4

28. Singh BN, Vaughan Williams EM. A fourth class of antidysrhythmic action? Effect of verapamil on ouabain toxicity, on atrial and ventricular intracellular potentials, and on other features of cardiac function. Cardiovasc Res 1972; 6: 109-119. https://doi.org/ 10.1093/ cvr/6.2.109

29. Harris AS, Kokernot RH. Effects of diphenylhydantoin sodium 
and phenobarbital sodium upon ectopic ventricular tachycardia in acute myocardial infarction. Am J Physiol 1950; 163: 505-516.

30. Glazko AJ. Discovery of Fenitoin. Therapeutic Drug Monitoring 1986; 8: 490-497.

31. Biltz H. Uber die konstitution der einwirkungsproducte von substitutierten harnstoffen auf benzil und uber einige neue methoden zur dartstellung der 5.5-diphenyil-hydantoine. Der D Chem Gasselshift 1908; 41: 1379-93. https://doi.org/10.1002/cber.190804101255

32. Wang LW, Subbiah RN, Kilborn MJ, Dunn RF. Fenitoin: an old but effective antiaritmic agent for the suppression of ventricular tachykardia. The Medical Journal of Australia 2013; 199: 209-211. https://doi.org/10.5694/mja13.10224

33. Eddy JD, Singh SP. Treatment of cardiac aritmias with fenitoin. Br Med J 1969; 4: 270-273. https://doi.org/10.1136/bmj.4.5678.270 34. Clyne CA, Estes NAM, Wang PJ. Moricizine; N Engl J Med 1992; 327: 255-260. https://doi.org/10.1056/NEJM199207233270407

35. Sneader W. (2006). Drug discovery: a history. Chichester: John Wiley \& Sons.

36. Pugsley MK. Antiaritmic drug development: Historical review and future perspective. Drug Development Research 2002; 55 : 3-16. https://doi.org/10.1002/ddr.10036

37. Kreeger RW, Hammill SC. New Antiaritmic Drugs: Tocainide, Mexiletine, Flecainide, Encainide, and Amiodarone. Mayo Clinic Proceedings 1987; 62: 1033-1050. https://doi.org/10.1016/S00256196(12)65077-0

38. Bowman WC, Rand MJ. Peripheral adrenergic mechanisms In: Textbook of pharmacology. Oxford: Blackwell Scientific Publications; 1980. P. 11.1-11.49.

39. CAST Investigators. Preliminary report: effect of encainide and flecainide on mortality in a randomized trial of arrhythmia suppression after myocardial infarction. N Engl J Med 1989; 321: 406-412.

40. CAST-II Investigators. Effect of the antiarrhythmic agent moricizine on survival after myocardial infarction. The Cardiac Arrhythmia Suppression Trial II Investigators. N Engl J Med 1992; 327: 227-233. https://doi.org/10.1056/NEJM199207233270403

41. Myerburg RJ, Kessler KM, Chakko S, et al. Future evaluation of antiarrhythmic therapy. Am Heart J 1994; 127: 1111-1118. https://doi. org/10.1016/0002-8703(94)90097-3

42. Vaughan Williams EM. Adaptation to prolonged interruption of sympathetic drive, and protection against sudden death. In: Riemersma RA, Oliver $\mathrm{N}$, editors. Catecholamines in the nonischaemic and ischaemic myocardium. Amsterdam: North-Holland Biomedical Press: 1982. P. 145-153.

43. Cairns JA, Connolly SJ, Gent M, Roberts R. Post-myocardia infarction mortality in patients with ventricular premature depolarizations. Canadian Amiodarone Myocardial Infarction Arrhythmia Tria Pilot Study. Circulation 1991; 84: 550-557. https://doi.org/10.1161/01. CIR.84.2.550

44. Julian DG, Camm AJ, Frangin G, et al. Randomised trial of effect of amiodarone on mortality in patients with left-ventricular dysfunction after recent myocardial infarction: EMIAT. European Myocardial Infarct Amiodarone Trial Investigators. Lancet 1997; 349: 667-674. https://doi.org/10.1016/S0140-6736(96)09145-3

45. McKibbin JK, Pocock WA, Barlow JB, et al. Sotalol, hypokalaemia, syncope, and torsade de pointes. Br Heart J 1984; 51: 157162. https://doi.org/10.1136/hrt.51.2.157

46. Jackman WM, Friday KJ, Anderson JL, et al. The long QT syndromes: a critical review, new clinical observations and a unifying hypothesis. Prog Cardiovasc Dis 1988; 31: 115-172. https://doi.org/10.1016/0033-0620(88)90014-X

47. Nattel S. Antiarrhythmic drug classifications. A critical appraisal of their history, present status, and clinical relevance. Drugs 1991; 41: 672-701. https://doi.org/10.2165/00003495-199141050-00002
48. Takanaka C, Singh BN. Barium-induced nondriven action potentials as a model of triggered potentials from early after depolarizations: significance of slow channel activity and differing effects of quinidine and amiodarone. J Am Coll Cardiol 1990; 15: 213-221. https://doi.org/10.1016/07351097(90)90205-4

49. Colatsky TJ, Follmer $\mathrm{CH}$. $\mathrm{K}^{+}$channel blockers and activators in cardiac arrhythmias. Cardiovasc Drug Rev 1989; 7:199-209. https:// doi.org/10.1111/j.1527-3466.1989.tb00527.x

50. Katritsis D, Camm AJ. New class III antiarrhythmic drugs. Eur Heart J 1993, 14S: 93-99. https://doi.org/10.1093/eurheartj/14. suppl_H.93

51. Saliba WI. Dofetilide (Tikosyn): a new drug to control atrial fibrillation. Cleve Clin J Med 2001; 68: 353-363.

52. Lee KS. Ibutilide, a new compound with potent class III antiarrhythmic activity, activates a slow inward $\mathrm{Na}+$ current in guinea pig ventricular cells. J Pharmacol Exp Ther 1992; 262: 99-108.

53. Abrol R, Page RL. Azimilide dihydrochloride: a new class III anti-arrhythmic agent. Expert Opin Investig Drugs 2000.; 9:27052715. https://doi.org/ 10.1517/13543784.9.11.2705

54. Janse MJ. To prolong refractoriness or to delay conduction (or both)? Eur Heart J 1992; 13(Suppl F): 14-18.

55. Colatsky TJ, Spinelli W, Follmer $\mathrm{CH}$. Molecular mechanisms of potassium channel block by antiarrhythmic drugs. In: Singh BN, Wellens HJJ, Hiraoka M. editors. Electropharmacological control of cardiac arrhythmias. New York: Futura Publishing; 1994. P. 335-359.

56. Singh BN. Amiodarone: historical development and pharmacological profile. Am Heart J 1983; 106: 788-799. https://doi. org/10.1016/0002-8703(83)90002-9

57. Campbell TJ. Proarrhythmic actions of antiarrhythmic drugs: a review. Aust NZ J Med 1990; 20: 275-82. https://doi.org/10.1111/j.1445-5994.1990.tb01039.x

58. Dhein S, Muller A, Gerwin R, et al. Comparative study on the proarrhythmic effects of some antiarrhythmic agents. Circulation 1993; 87: 617-30. https://doi.org/10.1161/01.CIR.87.2.617

59. Lengyel C, Varró A, Tábori K, Papp JG, Baczkó I. Combined pharmacological block of $I_{\mathrm{Kr}}$ and $\mathrm{I}_{\mathrm{Ks}}$ increases short-term QT interval variability and provokes torsades de pointes. British Journal of Pharmacology 2007; 151(7): 941-951. https://doi.org/10.1038/ sj.bjp.0707297

60. Nasraway SA, Rackow EC, Astiz ME, et al. Inotropic response to digoxin and dopamine in patients with severe sepsis, cardiac failure and systemic hypoperfusion. Chest 1989; 95: 612-15. https://doi. org/10.1378/chest.95.3.612

61. Holt AW. Hemodynamic responses to amiodarone in critically ill patients receiving catecholamine infusions. Crit Care Med 1989; 17: 1270-6.

62. Downey RA. Tachyarrhythmias. In: Manual of cardiovascular medicine. Eds. Griffin BP, Topol EJ, Nair D, Ashley K. 2009 Lippincott Williams \&Wilkins; p. 294-318.

63. Kirchhof P, Benussi S, Kotecha D, et al. 2016 ESC Guidelines for the management of atrial fibrillation developed in collaboration with EACTS. Europace 2016; 18: 1609-1678. https://doi.org/10.1093/ eurheartj/ehw210

64. Priori SG, Blomström-Lundqvist C, Mazzanti A, et al. 2015 ESC Guidelines for the management of patients with ventricular arrhythmias and the prevention of sudden cardiac death: The Task Force for the Management of Patients with Ventricular Arrhythmias and the Prevention of Sudden Cardiac Death of the European Society of Cardiology (ESC). Endorsed by: Association for European Paediatric and Congenital Cardiology (AEPC). Eur Heart J 2015; 36: 2793-867. https://doi.org/10.1093/eurheartj/ ehv316 